\title{
Controller Design of DFIG Based Wind Turbine by Using Evolutionary Soft Computational Techniques
}

\author{
Om Prakash Bharti \\ Dpt of Electrical Engineering \\ Indian Institute of Technology \\ Banaras Hindu University \\ Varanasi-221005, (U.P), India \\ opiitbhu@gmail.com
}

\author{
R. K. Saket \\ Dpt of Electrical Engineering \\ Indian Institute of Technology \\ Banaras Hindu University \\ Varanasi-221005, (U.P), India \\ rksaket.eee@iitbhu.ac.in
}

\author{
S. K. Nagar \\ Dpt of Electrical Engineering \\ Indian Institute of Technology \\ Banaras Hindu University \\ Varanasi-221005, (U.P), India \\ sknagar.eee@iitbhu.ac.in
}

\begin{abstract}
This manuscript illustrates the controller design for a doubly fed induction generator based variable speed wind turbine by using a bioinspired scheme. This methodology is based on exploiting two proficient swarm intelligence based evolutionary soft computational procedures. The particle swarm optimization (PSO) and bacterial foraging optimization (BFO) techniques are employed to design the controller intended for small damping plant of the DFIG. Wind energy overview and DFIG operating principle along with the equivalent circuit model is adequately discussed in this paper. The controller design for DFIG based WECS using PSO and BFO are described comparatively in detail. The responses of the DFIG system regarding terminal voltage, current, active-reactive power, and DC-Link voltage have slightly improved with the evolutionary soft computational procedure. Lastly, the obtained output is equated with a standard technique for performance improvement of DFIG based wind energy conversion system.
\end{abstract}

Keywords-DFIG; Wind turbine; PID controller; Matlab; Simulink; model; PSO; BFO; Fitness; function

\section{Abbreviations:}

DFIG: Doubly Fed Induction Generator PID: Proportional Integral Derivative

PSO: Particle Swarm Optimization

BFO: Bacterial Foraging Optimization

WECS: Wind Energy Conversion Systems

WRSG: Wound rotor synchronous generator

PMSG: Permanent magnet synchronous generator

SCIG: Singly excited induction generator.

\section{INTRODUCTION}

Wind power is considered probably the optimum available renewable energy sources and has widely developed in recent years due to its advantages such as low pollution, comparatively low capital cost involved and the short gestation period [1]. There have been several types of generators for wind energy conversion configuration. The older approach involved synchronous generators whereas the recent approach focuses more on induction generators of different types [2]. Simple induction generators have a few weaknesses such as reactive power utilization and unregulated voltage profile during variable rotor speed. These problems can be solved by employing power electronic converter or regulators. The DFIG is a wound rotor induction machine that can operate in supersynchronous and sub-synchronous manner. The benefits of the DFIG as compared with fixed speed generators are that they improve power quality, reduce mechanical stress and fluctuations and exhibit excellent power imprisons [3]. The function of the DFIG associated with the grid is facilitated through a rotor as well as a network side converter. However, an inverter related to the rotor side is used to provide give a fundamental frequency to sustain stator frequency at an invariable stage, despite the variations in mechanical power. The control of DFIG presents a dual dilemma: to balance the velocity changes and reactive power. In reality, DFIGs should be cut off from the network while the voltage inequity is more than $6 \%$ [3]. It has been described that the torque pulsation could be concentrated by using injected recompense current in the DFIG rotor. In [4], authors presented a relevant study of a simplified model, in which the authors compare the fifth plus third order model of DFIG followed using the investigation under faulted circumstances. However, in [5], authors offered magnitude along with frequency control of network associated DFIG based on a coordinated model for wind power production [5]. The numerical differentiation based additive model approximately the nominal working position of DFIG was used. The effectiveness of such type models can be validated from the outcomes offered. The ranking of wind turbines from $800 \mathrm{~kW}$ to $3 \mathrm{MW}$ but wind farm assortment is $2 \mathrm{MW}$ to $200 \mathrm{MW}$ [7]. In this paper, we provide an alternate technique to design a controller for the DFIG system considered by [7, 8] using two bioinspired techniques. The obtained results are compared with existing solutions. The implementation of DFIG for voltage regulation at a remote location has been described in a previous work [21].

The global trend toward clean energy is an inspiration for more integration of wind-based electrical energy in power systems [9]. Vast and small wind turbines produce electrical energy for networks whereas they sustain stand-alone isolated areas like well [10]. However, the wind velocity changes radically depending on the environmental circumstances along with the time of operation. Therefore, there is a huge margin of speed difference. Such margins of speed alteration make the wound rotor induction machines appropriate for power 
generation through wind energy [11]. Wind turbines can run either at fixed speed (actually within a speed range about $1 \%$ ) or at varying speed [12]. For fixed speed wind turbines, induction generator is instantly coupled to the grid. Hence, for a fixed-speed system, the turbulence of the wind will result in power fluctuations, which influence power quality. Power electronic apparatus are used to control the DFIG based variable-speed wind turbine. DFIG based wind turbine aerodynamics has thoroughly been described in [13-16, 17].

\section{GENERAL IDEA AND WORKING PRINCIPLE OF DFIG}

A part of wound rotor induction generators, also known as DFIG, is one of the most frequently used scheme in the wind energy industries [18]. Currently, these types of generators are extensively accepted as one of the appropriate wind energy conversion systems. DFIG is in nature a wound rotor induction generator, and the rotor circuit is usually controlled by electric power devices to allow variable speed operation. DFIG stator winding associated directly to the grid by a power transformer and DFIG's power is usually ranged from a few kilowatts to several megawatts. The size for a rotor converter is about $30 \%$ of a full capacity converter. During low wind speed, more electrical energy could be acquired from a variable speed DFIG, in distinguishing with a fixed speed wind generator [2]. The advantages of using DFIG in WECS is described in [2]. Whereas in [19] DFIGs have two operating modes, in (i) mode $\mathrm{N}_{\mathrm{r}}>\mathrm{N}_{\mathrm{s}}, \mathrm{S}$ is $-\mathrm{ve}$, then generator in super-synchronous mode and both stators, as well as rotor windings, deliver power to the grid. while in (ii) mode $\mathrm{N}_{\mathrm{r}}<\mathrm{N}_{\mathrm{s}}, \mathrm{s}$ is $+\mathrm{ve}$ the generator in subsynchronous mode and stator winding delivers power to both the grid and the rotor winding. The mathematical modeling of DFIG is thoroughly explained in [20]. The machine data is available in per unit reactance form. A DFIG equivalent circuit can be seen in [21]. The sixth order relations for unbalanced operations, is as follows $[7,8]$ :

$G(S)=\frac{0.000324 s 6-1.75 s 5-2366 s 4+7.9 e 6 s 3+7.5 e 9 s 2+5 e 12 s+2.18 e 14}{s 6+2340 s 5+8.67 e 6 s 4+4.79 e 9 s 3+2.7 e 12 s 2+1.27 e 14 s+9.6 e 14}$

\section{PARTICLE SWARM OPTIMIZATION}

An overview and brief description for particle swarm optimization along with algorithm features is given in [22-28]. This approach is appropriate to solve nonlinear problems and is established on flock activities such as birds detect food using gathering. The first alternative of the PSO algorithm brings using having the inhabitants (named the swarm) for the applicant result (known as particles). These particles are turned in the search space using a few straightforward formulas. The motions of the particles are guided to their best-known position in the search space in addition to the entire swarm's most prestigious situation. Whenever an enhanced position is being detected, then it will move towards to guide the movement of the flock. The procedure is repetitive, furthermore using performing, so it is trusted, but not assured, that an adequate result will finally be detected. Here in this procedure, a set of particles is introduced in the d-dimensional search space using at random selecting velocity as well as position. The first situation of the particle is considered as the best place to initiate, as well as the velocity of the particle is updated based on experience to the other particles from the swarming population.

\section{A. A minute representation for the algorithm}

We set the values of PSO algorithm constants as inertia weight factor $\mathrm{W}=0.3$, along with acceleration constants $\mathrm{C}_{1}, \mathrm{C}_{2}$ $=1.5$. As we have to optimize three parameters that are; $\mathrm{K}_{\mathrm{P}}$, $\mathrm{K}_{\mathrm{D}}, \mathrm{K}_{\mathrm{I}}$ to the controller, and search optimal value in the threedimensional search space. So we arbitrarily formatted a swarm of " 100 " population in three-dimensional search space using $\left[\mathrm{X}_{\mathrm{i}, 1} \mathrm{X}_{\mathrm{i}, 2} \mathrm{X}_{\mathrm{i}, 3}\right]$ and $\left[\mathrm{V}_{\mathrm{i} 1} \mathrm{~V}_{\mathrm{i} 2} \mathrm{~V}_{\mathrm{i} 3}\right]$ as preliminary situation as well as velocity. Considered primary fitness function of each point along with the position with minimum fitness function is exhibited as $g_{\text {best }}$ (initial value of global best Optima) as well as

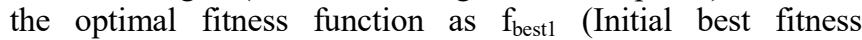
function). We ran the program by means of PSO algorithm through thousands (or yet additional numbers) of iterations; in addition to program brought back the final optimal value of fitness function as " $\mathrm{b}_{\text {best }}$ " along with last global optimum point as " $\mathrm{G}_{\text {best. }}$ "

\section{B. The conception of fitness function to the controller design}

For best results we optimize all PID parameters ,of the and describe a three-dimensional search space in which all three dimensions present. Every precise point in search space accounts for a particular arrangement of $\left[\mathrm{K}_{\mathrm{P}}, \mathrm{K}_{\mathrm{I}}\right.$, and $\left.\mathrm{KD}\right]$. For which an appropriate answer has found, and a fitness function determines the performance of the position to the PID parameters. This fitness function comprises numerous essential features to the performance index for design. Along with the best position in search space, the fitness function reaches an optimal value with four essential functions which defined fitness function. By this function; steady state errors, peak overshoot, rise time as well as settling time has been come out for the defined system. The contribution of these essential functions towards the innovative fitness function is determined by a scale factor. At best position fitness function has minimal value. The chosen fitness function is defined as follows:

$$
F=(1-E X P(-\beta))\left(M_{P}+E_{S S}\right)+(\operatorname{EXP}(-\beta))\left(T_{S}-T_{r}\right)
$$

Here F: Fitness function, $\mathrm{M}_{\mathrm{P}}$ : Peak Overshoot, $\mathrm{T}_{\mathrm{S}}$ : Settling Time, $T_{r}$ : Rise Time, $\beta$ : Scaling Factor (Depends on upon the alternative of the designer), scaling factor $\beta=1$. In the Matlab library, we have to define a fitness function which has PID parameters as input values, as well as it returns fitness value of the PID based controller model as output and formatted as follows. The Function $[\mathrm{F}]=$ fitness $\left(\mathrm{K}_{\mathrm{D}} \mathrm{K}_{\mathrm{P}} \mathrm{K}_{\mathrm{I}}\right)$

\section{PSO based controller gain}

The PSO based controller gains for the $6^{\text {th }}$ order transfer function reduced the model to the DFIG system, at best fitness function (fbest $=0.1967$ ) by several iterations which are given in Table I.

TABLE I. GAINS OF THE PSO-BASED CONTROLLER

\begin{tabular}{|c|c|c|c|}
\hline Gbest Parameters & $\mathrm{K}_{\mathrm{P}}$ & $\mathrm{K}_{\mathrm{I}}$ & $\mathrm{K}_{\mathrm{D}}$ \\
\hline Gains & 39.9781 & 7.6902 & 0.0271 \\
\hline
\end{tabular}




\section{BACTERIAL FORAGING OPTIMIZATION}

\section{A. Description}

A description for bacterial foraging optimization with algorithmic features is given [29-33]. The algorithm is heavily based on the behavior of E.colli bacteria. In the bacterial foraging optimization process four mobile behaviors are mimicked:

\section{1) Chemotaxis:}

A chemotactic step can be defined as a tumble followed by a tumble or a tumble a run lifetime. To represent a tumble a unit length random direction, $X(j)$, is generated; this will be used to describe the direction of movement after a tumble. In particular :

$$
X^{i}(j+1, k, 1)=X^{i}(j, k, 1)+C(i) * X(j),
$$

Where $X^{i}(j, k, l)$ represents the $i^{\text {th }}$ bacterium at $j^{\text {th }}$ chemotactic, $\mathrm{k}^{\mathrm{th}}$ reproductive as well as $\mathrm{l}^{\text {th }}$ elimination and dispersal step.C(i) is the size of the step taken in the random direction specified by a tumble( the run length unit).

\section{2) Swarming.}

E.Colli cells can work cooperatively self-organize into highly structured colonies with high environmental adaptability using a complex communication means. Overall, cells provide an attraction signal to each other, so they swarm together. The mathematical representation for swarming can be represented by:

$\operatorname{Jcc}(\theta, \mathrm{P}(\mathrm{j}, \mathrm{k}, \mathrm{l}))=\mathrm{J}^{\mathrm{i}} \operatorname{cc}\left(\theta, \theta^{\mathrm{i}}(\mathrm{j}, \mathrm{k}, \mathrm{l})\right)=\Sigma[$ Dattract $* \operatorname{EXP}(-$ Wattract $\left.\left.* \Sigma\left(\theta \mathrm{m}-\theta^{\mathrm{i}} \mathrm{m}\right)^{2}\right)\right]+\Sigma$ [Hrepellant * EXP (-Wrepellant $\left.\left.* \Sigma\left(\theta \mathrm{m}-\theta^{\mathrm{i}} \mathrm{m}\right)^{2}\right)\right]$

Where $\operatorname{Jcc}(\theta, P(j, k, 1))$ is the cost function value to be additional to the actual cost function, that is to be minimized to present a time-varying cost function. $\mathrm{S}$ is the total number of bacteria , $\mathrm{P}$ is the number of parameters to be optimized which are present in each bacterium and Dattract, Wattract,hrepellant, Wrepellant are different coefficients that should be appropriately chosen.

\section{3) Reproduction}

The least healthier bacteria die with the other each healthier bacteria split into two novel bacteria each placed in the similar position.

\section{4) Elimination and Dispersal:}

It is probable that in the local surroundings, the lives of a population of bacteria changes either gradually (e.g., via utilization of nutrients) or abruptly due to some other influence. Events can occur that all the bacteria in a region are killed, or a group is dispersed into a new part of the environment. They have the effect of possibly destroying the chemotactic progress.

\section{B. BFO based controller gain}

The BFO algorithm process as a flowchart is given in [33]. The BFO based controller gains for the $6^{\text {th }}$ order Transfer function reduced the model to the DFIG system, at the fitness function (function $\mathrm{F}=$ Fitness $\left(\mathrm{K}_{\mathrm{D}} \mathrm{K}_{\mathrm{P}} \mathrm{K}_{\mathrm{I}}\right)$ ) by several iterations which are given in Table II.
TABLE II. GAINS OF THE BFO-BASED CONTROLLER

\begin{tabular}{|c|c|c|c|}
\hline Parameters & $\mathrm{K}_{\mathrm{P}}$ & $\mathrm{K}_{\mathrm{I}}$ & $\mathrm{K}_{\mathrm{D}}$ \\
\hline Gains & 0.1417 & 0.1472 & 0.1005 \\
\hline
\end{tabular}

\section{SIMULATION AND RESULTS}

\section{A. Simulink response of the DFIG system}

Here Wind Farm - DFIG Average Model (MATLAB 13b) shows a 9 MW wind farm with the DFIG driven by a variable speed wind turbine. It consisted of six 1.5 MW wind turbines and linked toward a $25 \mathrm{kV}$ distribution system exports power to a $120 \mathrm{kV}$ grid through a $30 \mathrm{~km}, 25 \mathrm{kV}$ feeder. In this illustration, the wind velocity is preserved invariable at $15 \mathrm{~m} / \mathrm{s}$. The response of the DFIG based wind turbine with the evolutionary soft computational procedure (PSO-based controller) regarding voltage along with current at the terminals, active power generated; reactive power requirements and DC capacitor voltage in $\mathrm{Pu}$ are shown in Figures 1 and 2 respectively. AS shown, the response of the DFIG system regarding terminal voltage, current, active-reactive power and DC-Link voltage has slightly improved with the PSO based controller compared to the BFO based controller.
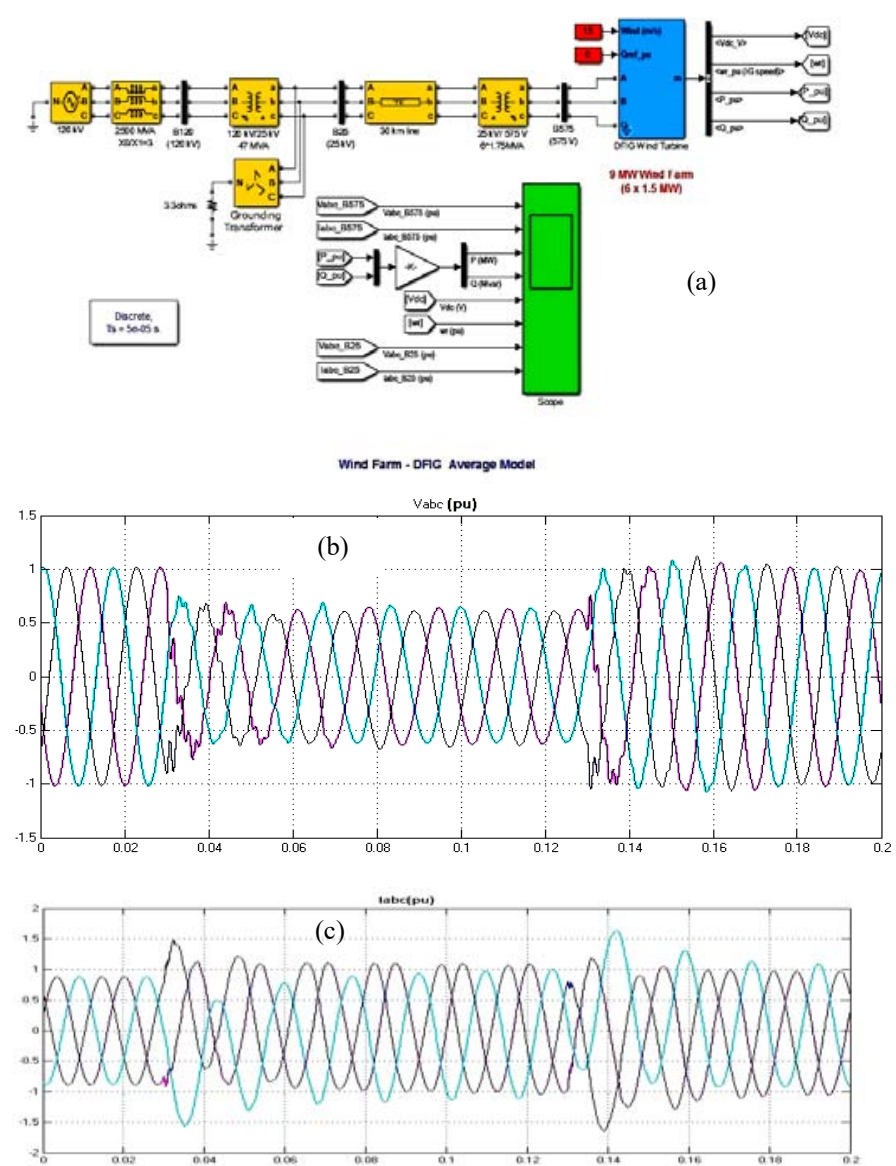

Fig. 1. (a) DFIG based wind turbine Average Matlab Simulink Model diagram, (b) Voltages at the DFIG terminals in Pu, (c) Currents at the DFIG terminals in $\mathrm{Pu}$ 


\section{B. BFO based Control Response by PID Controller}

The reaction of the BFO based PID controller is given in [7, 8]. As shown the system has zero undershot in the response of open loop system. The step response of the BFO based PIDcontroller is shown in Figure 3 and Table III.

\section{Response of PID Controller Using PSO Method}

The step response of the PSO based system is given in Figure 4. It is observable by a comparison result of BFO based PID control along with one describe in this work which shows that; PSO based PID controller has extended to sufficiently damped BFO based controller without compromising the speed of response to the control loop. Now the step response of open as well as close loop reduced order system by PID controller with the PSO technique is shown in Figure 4 and Table IV.

D. Comparison between BFO based PID controller and PIDcontroller using PSO method

By comparing Tables III and IV the following observations can be made:

- The designed PSO based PID controller can reduce the steady state error to zero as the existing one.

- The rise time, peak time and overshoot have been reduced to zero, and the response is no more underdamped.

- The speed response is much better than that of the current controller. Hence intended controller in this paper assists to eliminate reactive power variations in DFIG system.
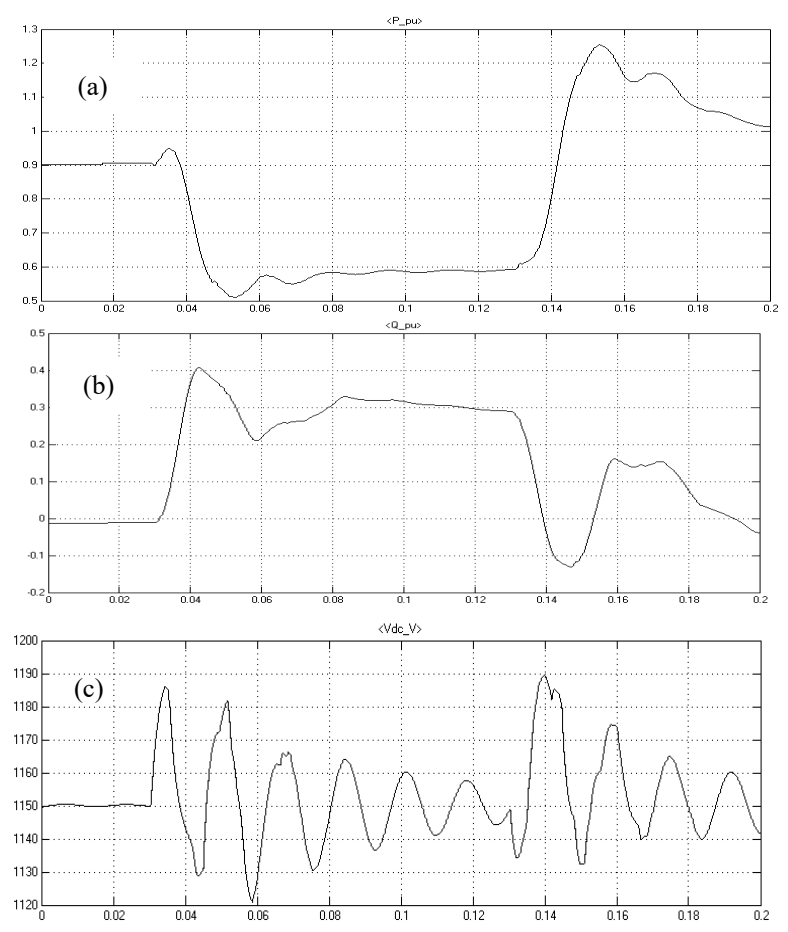

Fig. 2. (a) Active power delivered of the DFIG in Pu (b) Reactive power requirement of the DFIG in Pu (c) DC link voltage at the ordinary linkage capacitor

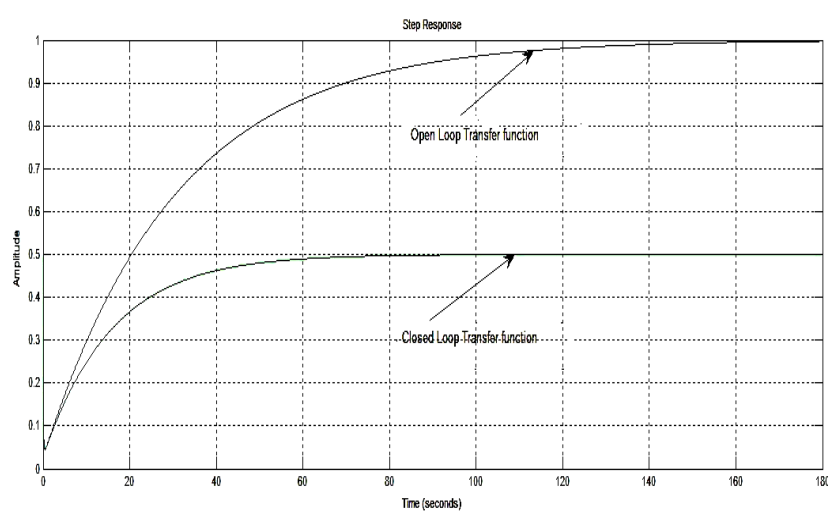

Fig. 3. Step response of the BFO based PID controller

TABLE III. STEP RESPONSE OF BFO BASED PID CONTROLLER

\begin{tabular}{|c|c|c|c|c|c|c|c|}
\hline $\begin{array}{c}\text { Rise } \\
\text { Time }\end{array}$ & $\begin{array}{c}\text { Settling } \\
\text { Time }\end{array}$ & $\begin{array}{c}\text { Settling } \\
\text { Min }\end{array}$ & $\begin{array}{c}\text { Settling } \\
\text { Max }\end{array}$ & $\begin{array}{c}\text { Over } \\
\text { Shoot }\end{array}$ & $\begin{array}{c}\text { Under } \\
\text { Shoot }\end{array}$ & Peak & $\begin{array}{c}\text { Peak } \\
\text { Time }\end{array}$ \\
\hline 0.00 & 62.3541 & 0.0438 & 0.4992 & $0.0 \%$ & $0.0 \%$ & 0.500 & 0.0 \\
$\mathrm{sec}$ & $\mathrm{sec}$ & $\mathrm{sec}$ & $\mathrm{sec}$ & & & & $\mathrm{sec}$ \\
\hline
\end{tabular}

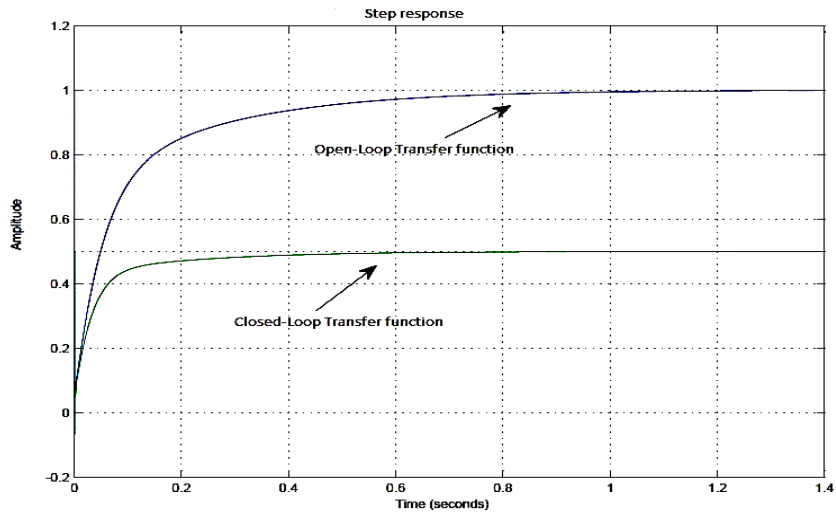

Fig. 4. Step response of the PSO-based PID controller

TABLE IV. STEP RESPONSE OF THE PSO-BASED PID CONTROLLER

\begin{tabular}{|c|c|c|c|c|c|c|c|}
\hline $\begin{array}{c}\text { Rise } \\
\text { Time }\end{array}$ & $\begin{array}{c}\text { Settling } \\
\text { Time }\end{array}$ & $\begin{array}{c}\text { Settling } \\
\text { Min }\end{array}$ & $\begin{array}{c}\text { Settling } \\
\text { Max }\end{array}$ & $\begin{array}{c}\text { Over } \\
\text { Shoot }\end{array}$ & $\begin{array}{c}\text { Under } \\
\text { Shoot }\end{array}$ & Peak & $\begin{array}{c}\text { Peak } \\
\text { Time }\end{array}$ \\
\hline $0 \mathrm{sec}$ & 0.4061 & -.0694 & 0.4996 & $0 \%$ & $13.8754 \%$ & 0.50 & 0 \\
& $\mathrm{sec}$ & $\mathrm{sec}$ & $\mathrm{sec}$ & & & & $\mathrm{sec}$ \\
\hline
\end{tabular}

\section{CONCLUSION}

The BFO based PID controller improves system responses in comparison with an open loop system, while the PSO based designed controller not only improves the system response but also reduces the percentage overshoot to zero. The obtained outcome demonstrates that the system using PSO based controller settles down in less time compared to the BFO based PID controller scheme. The comparison between the PSO based controller and the BFO based PID controller is discussed. It is accomplished that the settling time is condensed next to near about $62 \%$ along with the percentage overshoot; rise time and peak time are reduced to zero. Finally, it is fulfilled that PSO based control technique afford another alternative to 
propose a reliable and adequate controller to the DFIG based wind energy conversion systems.

\section{ACKNOWLEDGMENT}

The authors are highly thankful to the Indian Institute of Technology, Banaras Hindu University, Varanasi, Uttar Pradesh, India for partial funding this work.

\section{Appendix: DFIG Simulation Data}

Base values: $S_{b}=2 M V A, V_{b}=690 \mathrm{~V}, \omega_{b}=2 \Pi f(\mathrm{rad} / \mathrm{s}), f=60 \mathrm{~Hz}$, $Z_{d c}=V_{d c} / I_{d c}, \quad I_{b}=1900 \mathrm{~A}, V_{d c}=1150 \mathrm{~V}, Z_{b}=\left(V_{b} / \sqrt{ } 3\right) / I_{b}, \quad L_{b}=Z_{b} / \omega_{b}$, $L_{d c}=Z_{d c} / \omega_{b}, C_{b}=1 /\left(Z_{b} \omega_{b}\right), T_{b}=S_{b} / \omega_{b}, j_{b}=S_{b} /\left(\omega_{b}{ }^{2}\right), I_{d c}=S_{b} / Y_{d c}$, $C_{d c}=1 /\left(Z_{d c} \omega_{b}\right)$, Infinite bus voltage $(P u): V_{d q}$, inf $=\left[\begin{array}{lll}0.989 & 0.15\end{array}\right]$ DFIG $(\mathrm{Pu}): R_{s}=0.023, R_{r}=0.016, L_{s}=0.180, L_{r}=0.16$,

$L_{m}=2.9$, DC link component: $v_{d c}^{r e f}=1, \quad C_{d c}=12.7227$

\section{REFERENCES}

[1] F. Yao, R. C. Bansal, Z. Y. Dong, R. K. Saket, J. S. Shakya, "Wind Energy Resources: Theory, Design, and Applications", in: Handbook of Renewable Energy Technology, World Scientific Publishing House, Singapore, 2011

[2] M. Tazil, V. Kumar, R. C. Bansal, S. Kong, Z. Y. Dong, W. Freitas, H. D. Mathur, "Three-phase doubly fed induction generators: an overview". IET Electric Power Applications, Vol. 4, pp. 75-89, 2010

[3] T. Brekken, N. Mohan, "Control of a doubly fed induction wind generator under unbalanced grid voltage conditions", IEEE Trans. Energy Conv., Vol. 22, No. 1, pp. 129-135, 2007

[4] J. B. Ekanayake, L. Holdsworth, N. Jenkins, "Comparison of 5th order and 3rd order machine models for doubly fed induction generator (DFIG) wind turbines", Electric Power Systems Research, Vol. 67, pp. 207-215, 2003

[5] Z. Wang, Y. Sun, G. Li, B. T. Ooi, "Magnitude and frequency control of grid connected doubly fed induction generator based on synchronized model for wind power generation", IET Renewable Power Generation, Vol 4 , No. 3, pp 232-241, 2010

[6] H. Ko, G. Yoon, N. Kyung, W. Hong, "Modeling and control of DFIGbased variable speed wind-turbine", Electric Power Systems Research, Vol. 78, pp. 1841-1849, 2008

[7] O. P. Bharti, R. K. Saket, S. K. Nagar, "Controller Design For DFIG Driven By Variable Speed Wind Turbine Using Static Output Feedback Technique", Engineering, Technology \& Applied Science Research, Vol. 6, No. 4, pp-1056-1061, 2016

[8] D. Y. C. Leung, Y. Yang, "Wind energy development and its environmental impact: a review", Renewable and Sustainable Energy Reviews, Vol. 16, pp. 1031-1039, 2012

[9] R. Saidur, M. R. Islam, N. A. Rahim, K. H. Solangi, "A review on global wind energy policy", Renewable and Sustainable Energy Reviews, Vol. 14, pp. 1744-1762, 2010

[10] A. M. Atallah, A. Y. Abdelaziz, M. Ali, R. K. Saket, O. P. Bharti, "Reliability assessment and economic evaluation of offshore wind farm using stochastic probability", Advances in Intelligent Systems and Computing, Vol. 394, pp-25-37, 2016

[11] H. Polinder, J. A. Ferreira, B. B. Jensen, A. B. Abrahamsen, K. Atallah, R. A. McMahon, "Trends in Wind Turbine Generator Systems", IEEE Journal of Emerging and Selected Topics in Power Electronics, Vol. 1, No. 3, pp. 174-185, 2013

[12] N. D. Caliao, "Dynamic modeling and control of fully rated converter wind turbines", Renewable Energy, Vol. 36, pp. 2287-2297, 2011

[13] D. V. N. Ananth, G. V. Nagesh Kumar, T. Gayathri, "Analysis and Design of Enhanced Real and Reactive Power Control Schemes for Grid
Connected Doubly Fed Induction Generator", Annual IEEE India Conference, 2013

[14] F. Spertino, P. Di Leo, I. SorinIlie, G. Chicco, "DFIG equivalent circuit and mismatch assessment between the manufacturer and experimental power-wind speed curves", Renewable Energy, Vol. 48, pp. 333-343, 2012

[15] A. H. M. A. Rahim, I. O. Habiballah, "DFIG rotor voltage control for system dynamic performance enhancement", Electric Power Systems Research, Vol. 81, pp. 503-509, 2011

[16] T. Ackermann, Wind Power in Power Systems, John Wiley\& Sons, Ltd, 2005

[17] A. C. Smith, R. Todd, M. Barnes, P. J. Tavner, "Improved energy conversion for doubly fed wind generators", IEEE Transactions on Industry Applications, Vol. 42, pp. 1421-1428, 2006

[18] B. Fox, Wind power integration: connection and system operational aspects, Institution of E. Technology, London, 2007

[19] M. G. Simoes, F. A. Farret, Alternative energy systems: design and analysis with induction generators, CRC Press, 2008

[20] P. C. Krause, O. Wasynczuk, S. D. Sudhoff, Analysis of Electric Machinery and Drive Systems, John Wiley and Sons Inc., 2002

[21] N. K. Swami Naidu, B. Singh, "Eperimental Implementation of a Doubly Fed Induction Generator Used for Voltage Regulation at a Remote Location", IEEE Transactions on Industry Applications, Vol. 52, No. 6, pp. 5065-5072, 2016

[22] J. Kennedy, R. Eberhart, "Particle swarm optimization", in Proc. IEEE Int. Conf. Neural Networks, Vol. IV, Perth, Australia, pp. 1942-1948, 1995

[23] Y. Shi, R. C. Eberhart, "Empirical study of particle swarm optimization", in Proc. IEEE Int. Conf. Evol. Comput., Washington, DC, pp. 1945-1950, 1999

[24] R. C. Eberhart, Y. Shi, "Particle Swarm Optimization: Developments, Applications, and Resources", Proceedings of the IEEE Congress on Evolutionary Computation, May 27-30, 2001

[25] Z. L. Gaing, "A particle swarm optimization approach for the optimum design of PID controller in AVR system", IEEE Transaction on Energy Conversion, Vol.19, No. 2, pp. 384-391, 2004

[26] J. Zhao, T. Li, J. Qian, "Application of particle swarm optimization algorithm on robust PID controller tuning", in: Advances in Natural Computation, pp. 948-957, Springer Berlin, 2005

[27] S. Kahla, Y.Soufi, M. Sedraoui, M. Bechouat, "On-Off control based particle swarm optimization for maximum power point tracking of wind turbine equipped by DFIG connected to the grid with energy storage", International Journal of Hydrogen Energy, Vol. 40, No. 39, pp. 1374913758,2015

[28] M. R. Dastranj, M. Rouhani, A. Hajipoor, "Design of Optimal Fractional Order PID Controller Using PSO Algorithm", International Journal of Computer Theory and Engineering, Vol. 4, No. 3, pp. 429-432, 2012

[29] A. M. Hamza, M. S. Saad, H. M. Rashad, A. Bahgat, "Design of LFC and AVR for Single Area Power System with PID Controller Tuning By BFO and Ziegler Methods", International Journal of Computer Science and Telecommunications, Vol. 4, No. 5, pp. 12-17, 2013

[30] S. Das, A. Biswas, S. Dasgupta, "Bacterial Foraging Optimization Algorithm: Theoretical Foundations, Analysis, and Applications", in: Foundations of Computational Intelligence, LNEE Springer, Vol. 3, pp23-55, 2009

[31] D. R. Parhi, A. K. Jha, "Path Planning of Mobile Robot using Bacteria Foraging Optimization", International Journal of Artificial Intelligence and Computational Research, Vol.4, No. 1, pp. 1-5, 2012

[32] P. Siva Subramanian, R. Kayalvizhi, "An Optimum Setting of PID Controller for Boost Converter Using Bacterial Foraging Optimization Technique", in: Systems Thinking Approach for Social Problems, Lecture Notes in Electrical Engineering, Vol. 327, Springer, India, 2015

[33] C. Yadav, M. Singh, "BFO-PSO optimized PID Controller design using Performance index parameter", International journal of Engineering Development and Research, Vol. 3, No. 4, pp. 260-264, 2015 